\title{
Modulation of Diabetes and Dyslipidemia in Diabetic Insulin-Resistant Rats by Mangiferin: Role of Adiponectin and TNF- $\alpha$
}

\author{
SAMIRA SALEH ${ }^{1,2}$, NABILA EL-MARAGHY ${ }^{3,4}$, ENJI REDA $^{2,3}$ and WALEED BARAKAT ${ }^{3,5}$ \\ ${ }^{1}$ Cairo University, Department of Pharmacology and Toxicology, \\ Faculty of Pharmacy, Kasr El-Aini, Cairo, 11562, Egypt \\ ${ }^{2}$ October 6 University, Faculty of Pharmacy, Center Axis, Part 1/1, \\ Behind Sixth of October City-Giza Governorate, 12585, 6 October City, Egypt \\ ${ }^{3}$ Zagazig University, Department of Pharmacology and Toxicology, Faculty of Pharmacy, \\ Zagazig University, 44519, Zagazig, Egypt \\ ${ }^{4}$ Future University, Faculty of Pharmaceutical Sciences \& Pharmaceutical Industries, \\ Al Tagamoa El Khames, Main Center of Town, End of $90^{\text {th }}$ street, 11787, Cairo, Egypt \\ ${ }^{5}$ Department of Pharmacology and Toxicology, Faculty of Pharmacy, Tabuk University, \\ 71491, Tabuk, Kingdom of Saudi Arabia
}

Manuscript received on April 28, 2014; accepted for publication on August 6, 2014

\begin{abstract}
Mangiferin, present in Mangifera indica bark, was reported to produce hypoglycemic and antidiabetic activity in an animal model of genetic type 2 diabetes and in streptozotocin diabetic rats. Its effect on diabetic insulinresistant animals has not been investigated. The current work aimed to explore the effect of mangiferin on diabetic insulin-resistant rat model. Diabetes was induced by high-fat/high fructose diet for eight weeks followed by a subdiabetogenic dose of streptozotocin (HFD-Fr-STZ). Rats were treated with mangiferin ( $20 \mathrm{mg} / \mathrm{kg}$ i.p.) for 28 days starting one week after STZ and its effects were compared to the standard insulin sensitizer, rosiglitazone. HFD-Fr-STZ, induced obesity, hyperglycemia and insulin resistance accompanied by depletion in liver glycogen and dyslipidemia. Moreover, there was an elevation in serum TNF- $\alpha$ and a reduction in adiponectin. Mangiferin ameliorated the consequences of HFD-Fr-STZ and its actions were comparable to the effects of the standard insulin sensitizer, rosiglitazone. The results obtained in this study provide evidence that mangiferin is a possible beneficial natural compound for type 2 diabetes and metabolic disorders associated with the metabolic syndrome. This effect is mediated through improving insulin sensitivity, modulating lipid profile and reverting adipokine levels to normal.
\end{abstract}

Key words: Mangiferin, diabetes, dyslipidemia, adipokines, insulin resistance.

\section{INTRODUCTION}

Diabetes mellitus (DM) is a metabolic disorder characterized by increased glucose level and insulin deficiency and/or defects of insulin action (Sellamuthu et al. 2013a). Insulin resistance is common with obesity and predisposes to a variety

Correspondence to: Waleed Barakat

E-mail:waled055@yahoo.com of diseases, including diabetes, dyslipidemia, hypertension and cardiovascular problems (Moller and Flier 1991). Moreover, subclinical lowgrade inflammation plays an important role in the pathogenesis of insulin resistance (Pscherer et al. 2010). Furthermore, type 2 diabetes mellitus (T2DM) is associated with obesity, in particular, central adiposity (Flegal et al. 1998) and obesity is 
characterized by the growth of adipose tissue due to the enlargement of the adipocyte size (hypertrophy) and number (hyperplasia) (Faust et al. 1978). Adipocytes have a major role in the etiology of insulin resistance and in the pathogenesis of diabetes (Boyle 2004). Enlarged adipocytes and monocyte-derived macrophages alter expression and secretion of adipokines favoring a pro-inflammatory state, where the production of inflammatory cytokines such as TNF- $\alpha$ and IL- 6 are enhanced while the production of adiponectin, an anti-inflammatory adipokine, is reduced (Skurk et al. 2007). TNF- $\alpha$ is positively correlated with obesity and hyperinsulinemia (Kern et al. 2001). In contrast, a decrease in adiponectin level preceded the onset of diabetes in an obese insulin-resistant rodent model (Hotta et al. 2001). Additionally, adiponectin has antidiabetic properties and insulin sensitizing action (Zhou et al. 2010).

The natural C-glucoside xanthone, mangiferin is found in many plant species such as the Mangifera indica (Matkowski et al. 2013). Mangiferin has been reported to possess antidiabetic (Miura et al. 2001b), antioxidant (Sanchez et al. 2000), antitumor (Guha et al. 1996), antiviral (Yoosook et al. 2000) and immunomodulatory activities (Leiro et al. 2004). Mangiferin has been shown to have antidiabetic activity in KK/Ay mice, a genetic model of noninsulin-dependent diabetes mellitus (NIDDM) with hyperinsulinemia (Miura et al. 2001b).

The present study was designed to investigate the effects of mangiferin on a rat model of T2DM that mimics the unhealthy dietary habits as well as metabolic features of human T2DM in comparison to the standard thiazolidinedione insulin sensitizer; rosiglitazone.

\section{MATERIALS AND METHODS}

ANIMALS

Adult male Wistar rats, weighing 80-120g, were obtained from the National Research Center, Cairo, Egypt. They were kept under constant environmental conditions and had free access to normal pellet diet and water ad libitum, prior to dietary manipulation. This study was carried out in accordance with The Code of Ethics of the EU Directive 2010/63/EU for animal experiments and was approved by the Ethical Committee for Animal Handling at Zagazig University (ECAHZU).

\section{DRUGS AND CHEMICALS}

Mangiferin, Streptozotocin (STZ) and Dimethyl sulphoxide (DMSO) were purchased from Sigma (USA). Rosiglitazone maleate (Avandia ${ }^{\circledR}$ ) was purchased from Smith Kline Beecham Pharmaceutical, Egypt, and Insulin (Mixtard ${ }^{\circledR}$ ) was purchased from Novo Nordisk A/S, Denmark.

INDUCTION OF DIABETIC INSULIN-RESISTANT RATS

Induction of diabetic insulin-resistant rats was done according to the method described previously (Schaalan et al. 2009) with slight modification. Briefly, rats were fed $10 \%$ of their body weight with high fat diet (HFD, $14 \%$ saturated animal fat and $1 \%$ cholesterol powder, $60 \%$ carbohydrate, $21 \%$ protein, $3 \%$ fibers, $1 \%$ vitamins and minerals, (Reed et al. 2000)) and had free access to water containing $20 \%$ fructose (w/v) for 8 weeks.

At the $7^{\text {th }}$ week, animals received a daily dose of dual-acting insulin (Mixtard $0.5 \mathrm{IU} / \mathrm{Kg}$ ) for one week to prevent the reduction of insulin level following STZ injection (Reaven and Ho 1991) and to augment the insulin resistance mechanism (Chang et al. 1999). At this stage, animals were referred to as obese resistant rats.

At the beginning of the $8^{\text {th }}$ week, rats received a single i.p. injection of a subdiabetogenic dose (Reed et al. 2000) of freshly prepared STZ (35 $\mathrm{mg} / \mathrm{kg}$ ) in citrate buffer $(0.09 \mathrm{M}, \mathrm{PH} 4.8)$ after overnight fasting (Reaven and Ho 1991, Srinivasan et al. 2005) and were given 5\% glucose solution to drink during the first 24 hours after STZ administration to overcome hypoglycemia. Then the animals were fed with normal diet for the rest of the study. 


\section{EXPERIMENTAL DESIGN}

One week after STZ injection, animals that fulfilled the following criteria; obesity (body weight $250 \pm$ $20 \mathrm{gm})$, persistent blood glucose level exceeding $300 \mathrm{mg} / \mathrm{dl}$, hyperinsulinemia, and dyslipidemia, were used in the study (diabetic resistant rats, HFD-Fr-STZ).

The animals were randomly allocated into 4 groups $(n=8-10)$ : Control: rats were kept on normal diet and water during the whole study (12 weeks), Diabetic resistant rats: rats that fulfilled the previously mentioned criteria, Mangiferin: diabetic resistant rats treated with Mangiferin $(20 \mathrm{mg} / \mathrm{kg} /$ day in DMSO, i.p (Muruganandan et al. 2005)) for 28 days and Rosiglitazone: diabetic resistant rats treated with rosiglitazone $(4 \mathrm{mg} / \mathrm{kg} / \mathrm{day}$, orally in CMC (Chao et al. 2000)) for 28 days.

\section{SAMPLING AND MEASUREMENTS}

After $12 \mathrm{hrs}$ of the last dose of treatment: blood was collected from the orbital sinus of rats using heparinized microcapillary tubes according to the method of (Sorg and Buckner 1964) into clean dry test tubes and centrifuged at $3700 \mathrm{rpm}$ for 20 minutes, and serum was frozen at $-20^{\circ} \mathrm{C}$. Following, the rats were sacrificed by decapitation and livers were isolated and stored at $-80^{\circ} \mathrm{C}$.

Serum glucose was determined colorimetrically using Randex reagent kit (Trinder 1969) and serum insulin concentration was estimated by radioimmunoassay (RIA) using coat -A- count insulin kit (Dalpe-Scott et al. 1982). Both insulin resistance and $\beta$-cell function were calculated by homeostasis model assessment (HOMA) (Matthews et al. 1985): Insulin resistance $($ HOMA-IR $)=($ serum glucose, $\mathrm{mmol} / \mathrm{L}$ x serum insulin, $\mu \mathrm{IU} / \mathrm{ml}) / 22.5$ and $\beta$ - Cell function $=($ serum insulin, $\mu \mathrm{IU} / \mathrm{ml} \times 20) /$ (serum glucose, mmol/L) - 3.5.

Triglyceride in serum and liver extracts (Bligh and Dyer 1959) were quantified using Randex reagent kit (Fossati and Prencipe 1982), while cholesterol in serum and liver extract were measured using Randex reagent kit (Allain et al. 1974). HDL-Cholesterol was measured in fresh serum (Lopes-Virella et al. 1977), and serum LDL-C was calculated from the following formula (Friedewald et al. 1972): LDL-C (mg/dl) = TC [HDL-C + (TG/5)], while atherogenic index was calculated from the following formula (Sagud et al. 2009): Atherogenic index = LDL-C / HDL-C

The liver glycogen was determined using EnzyChromTM Glycogen Assay Kit (Murat and Serfaty 1974).

Serum TNF- $\alpha$ and adiponectin were determined using solid phase Enzyme Linked Immuno Sorbent Assay (ELISA) using rat TNF- $\alpha$ kits (Markham et al. 1995) and rat adiponectin kit (Risch et al. 2006).

STATISTICAL ANALYSES

Data are expressed as mean \pm standard error of the mean (S.E.M.). Statistical analysis was performed using one way analysis of variance (ANOVA) followed by Tukey's post Hoc test using Graph pad Prism software version 5. For all analyses, the level of statistical significance was set at $\mathrm{P}<0.05$.

\section{RESULTS}

EfFects of Treatment on Body Weight, SERum Glucose, INSULIN, HOMA-IR AND B-CELL FUNCTION

Fig. 1a illustrates that the current dietary model resulted in a significant increase in body weight in diabetic resistant rats compared to control rats (244.5 \pm 8.31 vs $102.9 \pm 3.09 \mathrm{~g}$, at $\mathrm{P}<0.05)$. However, treatment with mangiferin and rosiglitazone did not cause any change in body weight in comparison to diabetic resistant group.

Fig. 1b demonstrates a significant increase in glucose level in diabetic resistant rats in comparison to control rats $(316 \pm 5.34$ vs $82.73 \pm 2.66 \mathrm{mg} / \mathrm{dl}$, at $\mathrm{P}$ $<0.05)$. Treatment with mangiferin and rosiglitazone resulted in a significant reduction in the serum glucose level in comparison to diabetic resistant group $(134.8 \pm 1.44$, and $115.8 \pm 1.42$ respectively vs $316 \pm 5.34 \mathrm{mg} / \mathrm{dl}$, at $\mathrm{P}<0.05$ ) (Fig. 1b). 
These changes in glucose level were accompanied by a significant elevation in insulin level in diabetic resistant rats compared to normal rats $(24.12 \pm 0.41$ vs $2.56 \pm 0.05 \mu \mathrm{IU} / \mathrm{dl}$, at $\mathrm{P}<0.05)$. Treatment with mangiferin, or rosiglitazone failed to cause any significant change in serum insulin level compared to diabetic resistant group (Fig. 1c).

The HOMA-IR was significantly increased in diabetic resistant rats when compared to control rats $(19.01 \pm 0.34$ vs $0.54 \pm 0.01$, at $\mathrm{P}<0.05)$ (Fig. 1d). Treatment with mangiferin, or rosiglitazone was effective in trimming down insulin resistance in comparison to diabetic resistant rats $(6.83 \pm 0.15$ and $4.95 \pm 0.15$ respectively vs $19.01 \pm 0.34$, at $\mathrm{P}<0.05$ ) (Fig. 1d).

$\beta$-cell function was not significantly changed in diabetic resistant rats when compared to that of the control group although a reduction was observed (Fig. 1e). Treatment with mangiferin or rosiglitazone increased $\beta$-cell function as compared with diabetic resistant group $(103.4 \pm 1.65$ and $118.5 \pm 3.1$ respectively vs $34.19 \pm 1.39$, at $\mathrm{P}<0.05$ ).

The changes in these parameters during the induction of the model (4 weeks HFD-Fr and obese resistant rats) are presented in Figure S1 (Supplementary material).

\section{EFFECTS OF TREATMENT ON SERUM LIPID PROFILE}

Fig. 2a shows that diabetic resistant rats had significantly higher serum triglycerides compared to control group $(170.4 \pm 1.11$ vs $48.25 \pm 1.31 \mathrm{mg} / \mathrm{dl}$, at $\mathrm{P}<0.05)$. Treatment with mangiferin or rosiglitazone caused a significant reduction in serum triglycerides compared with diabetic resistant group $(113.9 \pm 1.24$ and $103.7 \pm$ 1.97 respectively vs $170 \mathrm{mg} / \mathrm{dl}$, at $\mathrm{P}<0.05)$.

Similarly, there was a significant escalation in serum cholesterol level in diabetic resistant rats compared to control rats $(224.5 \pm 2.34$ vs $84.25 \pm 0.79$ $\mathrm{mg} / \mathrm{dl}$, at $\mathrm{P}<0.05)$. After treatment with mangiferin or rosiglitazone, a significant fall in serum cholesterol level was observed compared with diabetic resistant group $(166.6 \pm 1.7$ and $153.8 \pm 1.16$ respectively vs $224.5 \pm 2.34 \mathrm{mg} / \mathrm{dl}$, at $\mathrm{P}<0.05$ ) (Fig. $2 \mathrm{~b}$ ).
We also observed a significant elevation in LDL level in diabetic resistant rats compared to control group $(174.2 \pm 2.42$ vs $33.78 \pm 1.06 \mathrm{mg} /$ $\mathrm{dl}$, at $\mathrm{P}<0.05$ ), while treatment with mangiferin or rosiglitazone caused a significant decrease in LDL when compared with diabetic resistant rats (103.3 \pm 1.58 and $88.6 \pm 1$ respectively vs $174.2 \pm 2.42 \mathrm{mg} /$ $\mathrm{dl}$, at $\mathrm{P}<0.05$ ) (Fig. 2c).

The serum level of HDL dropped significantly in diabetic resistant rats compared to control group $(20.67 \pm 0.34$ vs $48.63 \pm 1.74 \mathrm{mg} / \mathrm{dl}$, at $\mathrm{P}<0.05)$, while treatment with mangiferin or rosiglitazone caused a significant elevation in HDL when compared with diabetic resistant rats $(39.38 \pm 0.46$ and $44.5 \pm 0.88$ respectively vs $20.67 \pm 0.34 \mathrm{mg} / \mathrm{dl}$, at $\mathrm{P}<0.05$ ) (Fig. 2d).

Accordingly, the atherogenic index in diabetic resistant rats was increased compared to control rats $(8.45 \pm 0.23$ vs $0.699 \pm 0.03$, at $\mathrm{P}<0.05)$ and was improved by treatment with mangiferin or rosiglitazone $(2.65 \pm 0.07$ and $1.98 \pm 0.06$ respectively vs $8.45 \pm 0.23$, at $\mathrm{P}<0.05$ ) (Fig. 2e).

The changes in these parameters during the induction of the model (obese resistant rats) are presented in Figure S2.

\section{EFFECT OF TREATMENT ON LIVER LIPID PROFILE AND}

GLYCOGEN CONTENT

Diabetic resistant rats had a significantly higher level of liver triglycerides compared to control rats (12.72 \pm 0.1 vs $3.48 \pm 0.09 \mathrm{mg} / \mathrm{g}$, at $\mathrm{P}<0.05)$, while, treatment with mangiferin or rosiglitazone caused a significant reduction in the liver TGs compared with the diabetic resistant group $(8.2 \pm 0.07$ and $7.23 \pm 0.1$ respectively vs $12.72 \pm 0.1 \mathrm{mg} / \mathrm{g}$, at $\mathrm{P}<$ 0.05) (Fig. 3a).

Liver cholesterol content was significantly higher in diabetic resistant rats compared to control rats $(14.85 \pm 0.11 \mathrm{vs} 4.73 \pm 0.09 \mathrm{mg} / \mathrm{g}$, at $\mathrm{P}<0.05)$, while, treatment with mangiferin, or rosiglitazone caused a significant reduction in the liver cholesterol content compared with the diabetic resistant group 

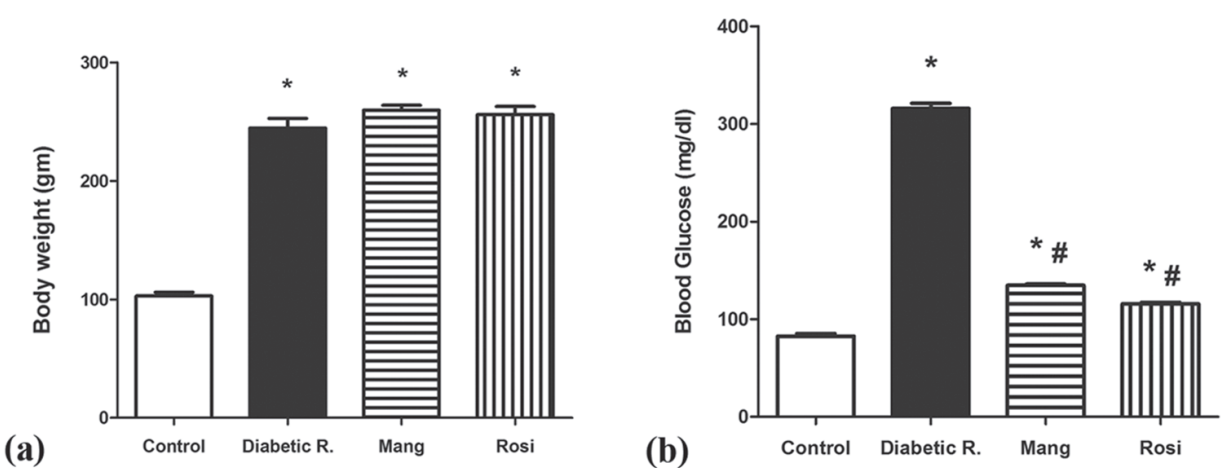

(c)
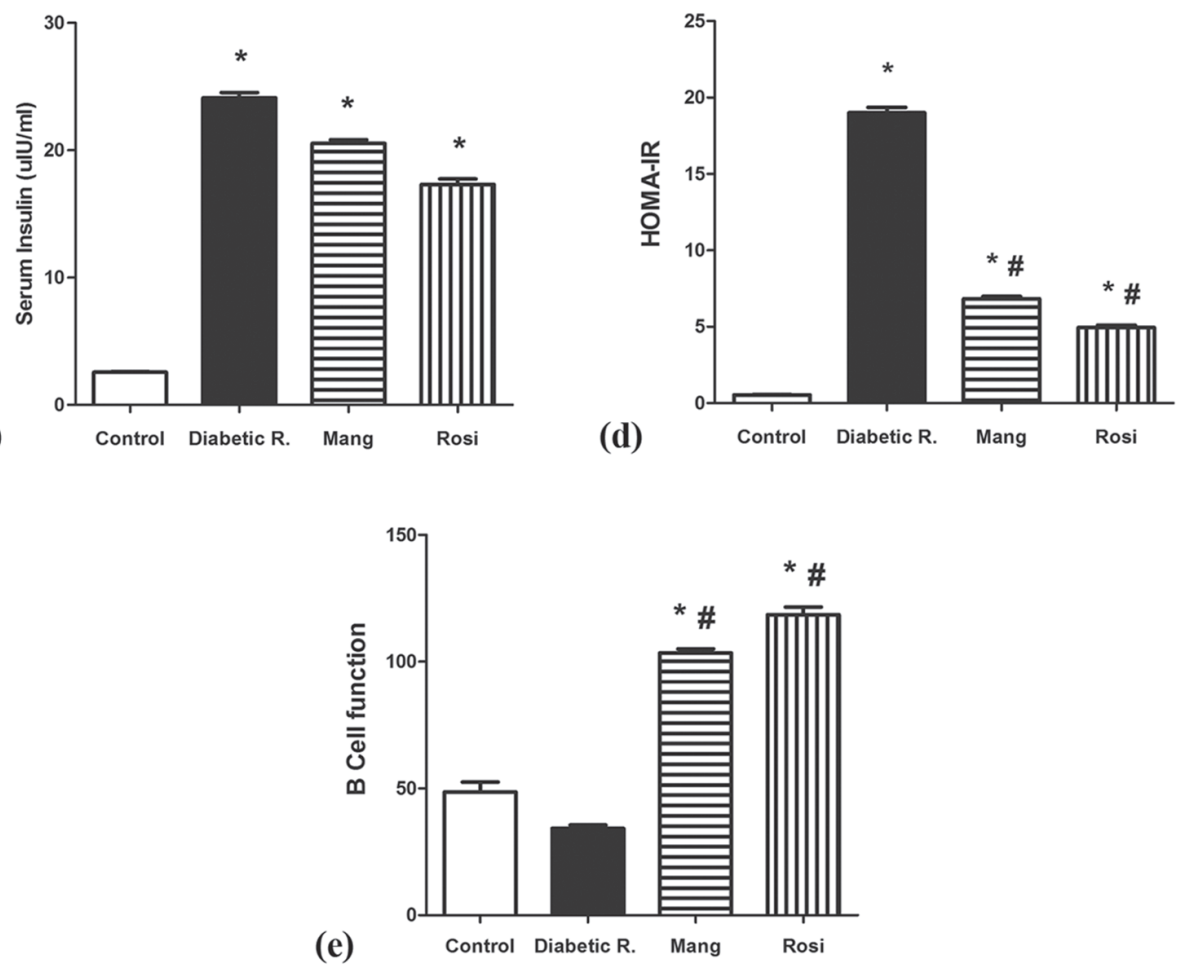

Figure 1 - Effect of HFD-Fr-STZ and treatment with mangiferin $(20 \mathrm{mg} / \mathrm{kg} / \mathrm{IP})$ and rosiglitazone (4 $\mathrm{mg} / \mathrm{kg} /$ orally) on: a) body weight, b) serum glucose level $(\mathrm{mg} / \mathrm{dl}), \mathrm{c})$ serum insulin level $(\mu \mathrm{IU} / \mathrm{ml})$, d) HOMA-IR and e) $\beta$-cell function. Data are presented as mean \pm S.E.M $(n=8-10)$ * Significantly different from control group, \# Significantly different from diabetic resistant group at $\mathrm{P}<0.05$ using one-way ANOVA followed by Tukey's post Hoc test.

$(11.37 \pm 0.08$ and $12.81 \pm 0.09$ respectively vs $14.85 \pm 0.11 \mathrm{mg} / \mathrm{g}$, at $\mathrm{P}<0.05$ ) (Fig. 3b).

In contrast, liver glycogen content was significantly depleted in diabetic resistant rats compared to control rats $(1.83 \pm 0.04$ vs $6.28 \pm 0.13$ $\mathrm{mg} / \mathrm{g}$, at $\mathrm{P}<0.05$ ), while, treatment with mangiferin or rosiglitazone caused a significant elevation in the liver glycogen content compared with the diabetic resistant group $(2.64 \pm 0.09$ and $2.33 \pm 0.03$ respectively vs $1.83 \pm 0.04 \mathrm{mg} / \mathrm{g}$ ) (Fig. 3c). 

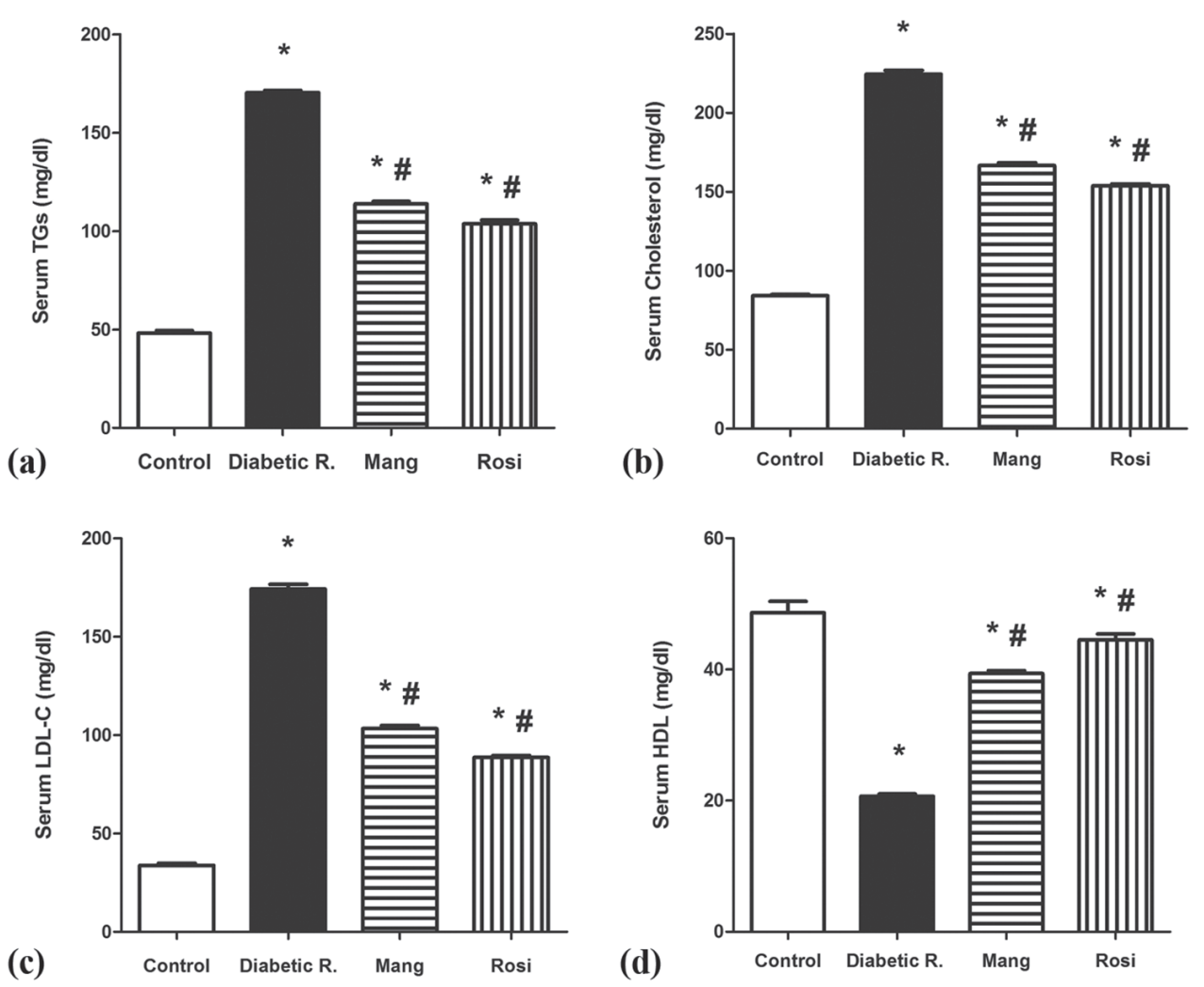

(d)

(e)

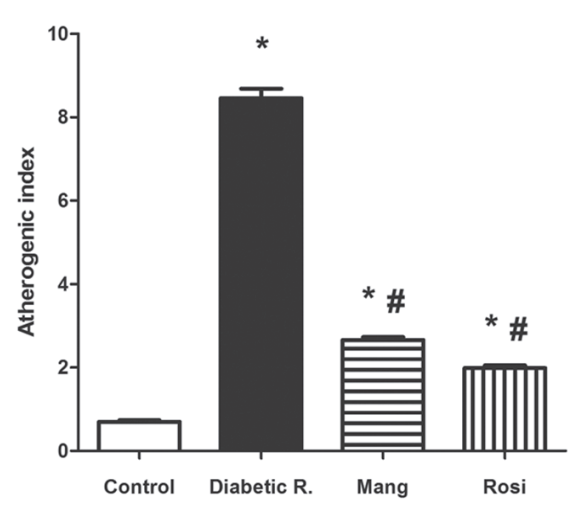

Figure 2 - Effect of HFD-Fr-STZ and treatment with mangiferin $(20 \mathrm{mg} / \mathrm{kg} / \mathrm{IP})$ and rosiglitazone $(4 \mathrm{mg} / \mathrm{kg} / \mathrm{orally})$ on: a) serum TG level (mg/dl), b) serum TC level (mg/dl), c) serum LDL-C level $(\mathrm{mg} / \mathrm{dl}) \mathrm{d})$ serum HDL-C level $(\mathrm{mg} / \mathrm{dl})$ and e) atherogenic index. Data are presented as mean \pm S.E.M ( $\mathrm{n}=8-10) .{ }^{*}$ Significantly different from control group, \# Significantly different from diabetic resistant group at $\mathrm{P}<0.05$ using one-way ANOVA followed by Tukey's post Hoc test.

\section{EFFECTS OF TREATMENT ON SERUM ADIPOKINES}

The serum level of TNF- $\alpha$ was significantly increased in diabetic resistant rats compared with control group $(256.2 \pm 2.98$ vs $16.5 \pm 0.67 \mathrm{pg} / \mathrm{ml}$, at $\mathrm{P}<0.05)$, while, treatment with mangiferin or rosiglitazone significantly reduced serum TNF- $\alpha$ compared with the diabetic resistant group (121.8 \pm 0.45 and $133.2 \pm 0.47$ respectively vs $256.2 \pm$ $2.98 \mathrm{pg} / \mathrm{ml}$, at $\mathrm{P}<0.05$ ) (Fig. 4a).

On the other hand, adiponectin level significantly declined in diabetic resistant group compared with control group $(0.95 \pm 0.04$ vs 3.85 
(a)

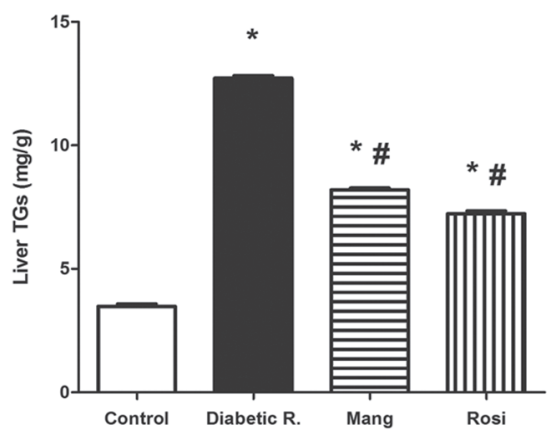

(b)

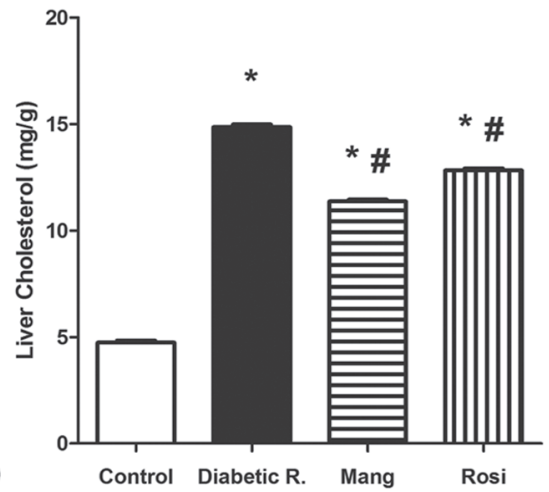

(c)

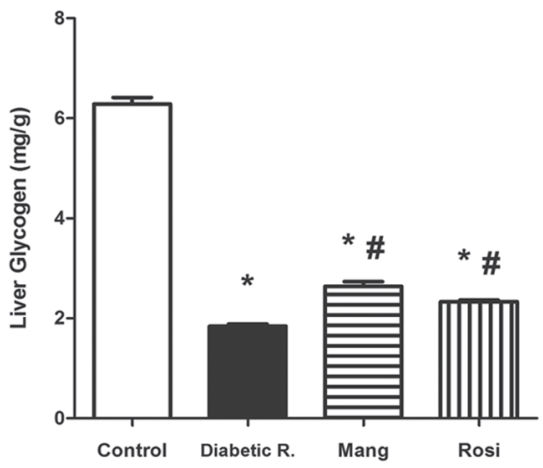

Figure 3 - Effect of HFD-Fr-STZ and treatment with mangiferin $(20 \mathrm{mg} / \mathrm{kg} / \mathrm{IP})$ and rosiglitazone $(4 \mathrm{mg} / \mathrm{kg} /$ orally) on: a) liver TG content (mg/gm tissue), b) liver TC content (mg/gm tissue) and c) glycogen content $(\mathrm{mg} / \mathrm{gm}$ tissue). Data are presented as mean \pm S.E.M $(\mathrm{n}=8-10)$ * Significantly different from control group, \# Significantly different from diabetic resistant group at $\mathrm{P}<0.05$ using one-way ANOVA followed by Tukey's post Hoc test.

$\pm 0.14 \mathrm{ng} / \mathrm{ml}$, at $\mathrm{P}<0.05$ ), while, treatment with mangiferin, or rosiglitazone caused a significant increase in serum adiponectin compared with the diabetic resistant group $(2.32 \pm 0.03$, and 2.15 \pm 0.02 respectively vs $0.95 \pm 0.4 \mathrm{ng} / \mathrm{ml}$, at $\mathrm{P}<$ 0.05) (Fig. 4b).

The changes in these parameters during the induction of the model (obese resistant rats) are presented in Figure S3.

\section{DISCUSSION}

Insulin resistance is a common feature of obesity and predisposes the affected individuals to a variety of diseases, including T2DM, dyslipidemia, hypertension and cardiovascular problems (Moller and Flier 1991).
In the present study, a rat model that mimics a typical unhealthy dietary habit as well as metabolic features of human T2DM (Aguila and Mandarimde-Lacerda 2003) was chosen. This model resulted in an increase in body weight, hyperglycemia, hyperinsulinemia and insulin resistance as reflected by elevated HOMA-IR. Similar results were previously reported in this model (Schaalan et al. 2009) and the resulting disorders closely mimic the metabolic features of human T2DM (Axelsen et al. 2010). In addition, this model resulted in a state of hyperlipidemia (elevation of serum triglycerides, cholesterol, LDL-C, atherogenic index and reduction in HDL-C) and triglycerides and cholesterol accumulated in the liver associated with 
(a)

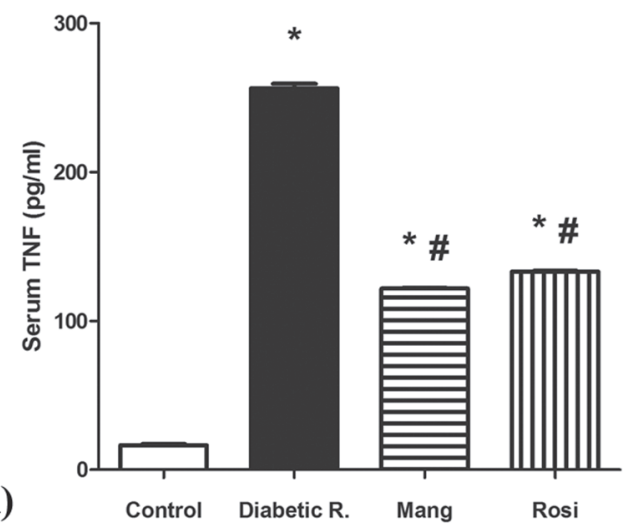

(b)

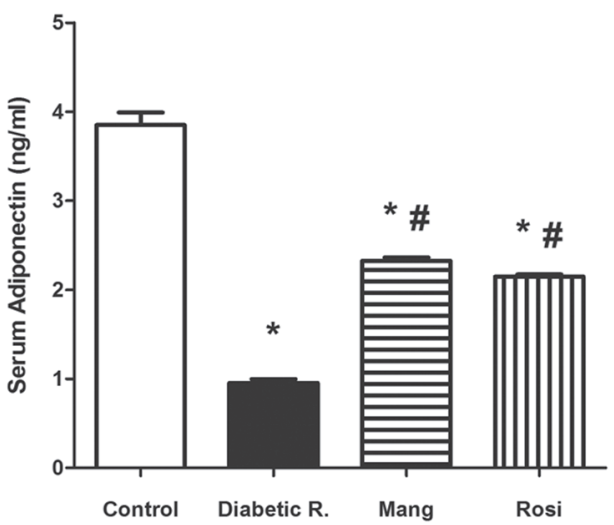

Figure 4 - Effect of HFD-Fr-STZ and treatment with mangiferin $(20 \mathrm{mg} / \mathrm{kg} / \mathrm{IP})$ and rosiglitazone (4 mg/kg/orally) on: a) serum TNF- $\alpha$ level (pg/ml) and b) serum adiponectin level (ng/ml). Data are presented as mean \pm S.E.M (n=8-10). * Significantly different from control group, \# Significantly different from diabetic resistant group at $\mathrm{P}<0.05$ using one-way ANOVA followed by Tukey's post Hoc test.

a reduction in liver glycogen content as supported by previous studies (Schaalan et al. 2009). This state is equivalent to the so called hepatic steatosis (Brewer 1999, Festi et al. 2004) or nonalcoholic steatohepatitis (NASH) (Puri et al. 2009). Clinical characteristics associated with hepatic steatosis include obesity, hyperlipidemia and diabetes mellitus, all of which have been partly attributed to insulin resistance (Harrison et al. 2002).

Fat accumulation in the liver was previously reported to be associated with impaired insulin clearance and hyperinsulinemia (Lim et al. 2009). Long term HFD-Fr was reported to upregulate the expression of hepatic sterol regulatory element binding protein (SREBP-1) and decrease the expression of PPAR- $\alpha$ receptor (Aragno et al. 2009). PPAR- $\alpha$ activation mediates expression of genes regulating lipid oxidation (Kersten et al. 2000). These results support the findings of the current study.

The current model, in addition, presented a decrease in adiponectin and an increase in TNF- $\alpha$ in diabetic resistant rats. Low adiponectin levels are found in insulin resistant states, such as obesity, diabetes mellitus and ischaemic heart disease (Hotta et al. 2000). It produces its action by binding to adiponectin receptor 1 and 2 expressed in the liver and skeleton muscle (Yamauchi et al. 2003) and activates PPAR- $\alpha$ and AMP-activated protein kinase (AMPK), thus enhancing insulin sensitivity and exerting anti-inflammatory action in NASH (Liu et al. 2011). Adipose tissues also produce TNF- $\alpha$ (Bastard et al. 2006), which inhibits insulinstimulated glucose uptake by adipose tissues and skeletal muscle and in turn, causes insulin resistance (Hotamisligil et al. 1993) in rodents. Therefore, the elevated levels of TNF- $\alpha$ in the current study may have led to the induction of insulin resistance and is, in part, responsible for hepatic fatty changes (Lonardo et al. 2005).

Herbal remedies are apparently efficient, produce the least or no harmful effects in clinical experience, and are comparatively of low costs as compared to oral synthetic antidiabetic agents (Hung et al. 2012). Nowadays, natural therapies gain importance as they have been shown to regulate complications of diabetes (Arulselvan and Subramanian 2007).

In this study, treatment with mangiferin restored the disturbed glucose homeostasis and improved insulin sensitivity as indicated by the HOMA-IR and $\beta$-cell function, indicating that it can improve insulin resistance. Similar actions of mangiferin 
were previously reported (Sellamuthu et al. 2014). Mangiferin was reported to decrease oxidative stress and pancreatic $\beta$-cell damage in streptozotocininduced diabetes in rats (Sellamuthu et al. 2013b).

Different mechanisms have been proposed for the hypoglycemic effect of mangiferin. These include enhancement of insulin release/ secretion (insulinotropic effect) (Jouad et al. 2000), stimulation of peripheral glucose utilization, enhancing glycogenic process with concomitant decrease in glycogenolysis and gluconeogenesis (Saxena and Vikram 2004). Furthermore, it is also likely that it might reduce blood glucose level by inhibiting glucose absorption from the intestine because mangiferin inhibits $\alpha$-glucosidase enzymes (Yoshikawa et al. 2001) which are involved in the digestion of carbohydrate into simple sugars in the gut leading to delay or inhibition of carbohydrate breakdown and subsequent glucose absorption from theintestine(Emilienetal. 1999).Asimilar observation was previously reported after intraperitoneal administration of mangiferin in streptozotocin diabetic rats (Muruganandan et al. 2005) which was attributed to the enterohepatic circulation.

In addition, mangiferin was able to correct the disturbed lipid profile in serum and liver. Similar effects of mangiferin in improving dyslipidemia were previously reported in streptozotocin diabetic rats (Guo et al. 2011, Muruganandan et al. 2005). Mangiferin may mediate its action on lipid profile through increasing fatty acid uptake in the liver via upregulation of the expression of fatty acid translocase (Guo et al. 2011), downregulation of microsomal triglyceride transfer protein (MTP) and upregulation of hepatic PPAR- $\alpha$ expression (Guo et al. 2011). According to the Randle's glucose-fatty acid cycle, increased plasma triglycerides and increased free fatty acid (FFA) oxidation impairs insulin action, glucose metabolism and utilization leading to hyperglycemia and consequently, reduction of triglycerides could participate to the hypoglycemic effect of mangiferin (Randle et al. 1963).
As mentioned earlier, inflammatory pathways hold a substantial role in insulin resistance in type 2 diabetes. Therefore, diabetes therapy should not focus only on glycemic control but also on mechanisms to control inflammation and hence improve insulin resistance.

In the present study, mangiferin caused a reduction of serum TNF- $\alpha$ and an elevation of serum adiponectin production which may be attributed to activation of PPAR- $\gamma$ as mentioned earlier (Giron et al. 2009), which is known to induce the expression of adiponectin (Iwaki et al. 2003). Furthermore, previous reports have demonstrated the ability of mangiferin to block the expression of TNF- $\alpha$ (Leiro et al. 2004). The suppression of TNF- $\alpha$ is known to cause activation of PP-1 allowing insulin to activate glycogen storage (Ragolia and Begum 1998), and reduction of FFA availability resulting in inhibition of both gluconeogenesis and glycogenolysis (Ruan et al. 2003) and reduction in the availability of FFAs for synthesis of VLDL (Yoon et al. 2006). On the other hand, the elevation of adiponectin activates GSK3 $\beta$, a key molecule involved in regulating glycogen homeostasis (Zhou et al. 2010). The mechanisms by which adiponectin ameliorates insulin sensitivity include increased peripheral glucose uptake and suppressed hepatic glucose production (Lim et al. 2009).

Mangiferin was previously shown to have no action on blood glucose level in normal rats (Miura et al. 2001a, Muruganandan et al. 2005) and it was also shown not to modify insulin secretion from isolated pancreatic islets from healthy Wistar rats (Hoa et al. 2004). However, the effects of mangiferin on serum and liver lipid profile was not tested in normal rats before and needs to be investigated in future research.

Concerning the reference drug, rosiglitazone corrected the disturbed lipid profile in serum and liver. A previous study has shown that rats treated with rosiglitazone had lower serum TGs, insulin, liver TGs associated with elevation in 
liver glycogenesis (Seda et al. 2002). Clinically, rosiglitazone is able to reduce steatosis and transaminase levels in NASH patients (Ratziu et al. 2008) and these changes were associated with elevation in adiponectin level (Holguin et al. 2007).

Finally, rosiglitazone attenuated the disturbed secretion of TNF- $\alpha$ and adiponectin. This confirms earlier work displaying that TNF- $\alpha$ was markedly decreased and adiponectin receptor expression was attenuated by rosiglitazone (Liu et al. 2011).

\section{CONCLUSION}

The present study has demonstrated the beneficial effect of mangiferin in HFD-Fr-STZ-treated rats, a model that mimics most of the metabolic features of human T2DM. These actions were comparable to the standard insulin sensitizer, rosiglitazone indicating the possible clinical impact of mangiferin in type-2 diabetic patients. Based on the results of the current study, the effects of mangiferin might be attributed to its ability to correct the disturbed level of serum adipokines resulting in a reduction in TNF- $\alpha$ and an elevation in adiponectin which is expected to improve insulin action leading to better glycemic control and correct the disturbed lipid profile in both serum and liver. However, other mechanisms might be involved in mediating these actions of mangiferin and require further investigation. In addition, the possible use of mangiferin against diabetic complications seems a promising target. The authors declare that they have no conflict of interest.

\section{ACKNOWLEDGMENTS}

The authors would like to acknowledge Zagazig University funding program $(8 \mathrm{~K} 2 / \mathrm{M} 3,2009)$ for partially funding Dr. Waleed Barakat.

\section{RESUMO}

Foi verificado que a mangiferina, presente na casca de Mangifera indica, apresenta atividade hipoglicemiante e antidiabética em um modelo animal de diabetes tipo 2 de origem genética e em ratos diabéticos tratados com estreptozotocina (STZ). Seu efeito em animais diabéticos resistentes à insulina ainda não foi investigado. $\mathrm{O}$ presente trabalho objetivou explorar o efeito de mangiferina em ratos diabéticos resistentes à insulina. $\mathrm{O}$ quadro diabético foi induzido por uma dieta com alto conteúdo de gordura e frutose por oito semanas, seguida de uma dose sub-diabetogênica de estreptozotocina (HFD-Fr-STZ). Uma semana após o tratamento com STZ os ratos foram tratados com mangiferina $(20 \mathrm{mg} /$ $\mathrm{kg}$ i.p.) por 28 dias e seus efeitos foram comparados os sensibilizador insulinérgico padrão, a rosiglitazona. A combinação HFD-Fr-STZ induziu obesidade, hiperglicemia e resistência à insulina, acompanhada por depleção de glicogênio hepático e dislipidemia. Além disso, houve uma elevação no TNF-alfa sérico e uma redução de adiponectina. A mangiferina melhorou as consequências do tratamento HFD-Fr-STZ e suas ações foram comparáveis aos efeitos do sensibilizador insulinérgico padrão, rosiglitazona. Os resultados obtidos neste estudo fornecem evidências que a mangiferina é um composto natural possivelmente benéfico para o tratamento do diabetes tipo 2 e de desordens metabólicas associadas à síndrome metabólica. Este efeito é mediado pela melhora da sensibilidade à insulina, modulando o perfil lipídico e revertendo os níveis de adipocinas à normalidade.

Palavras-chave: mangiferina, diabetes, dislipidemia, adipocinas, resistência à insulina.

\section{REFERENCES}

AgUila MB AND MANDARIM-DE-LACERDACA. 2003. Heart and blood pressure adaptations in Wistar rats fed with different high-fat diets for 18 months. Nutrition 19: 347-352.

Allain CC, PoOn LS, Chan CS, Richmond W AND Fu PC. 1974. Enzymatic determination of total serum cholesterol. Clin Chem 20: 470-475.

Aragno M, Tomasinelli CE, Vercellinatto I, Catalano MG, COLLINO M, FANTOZZI R, DANNI O AND BocCuZZI G. 2009. SREBP-1c in nonalcoholic fatty liver disease induced by Western-type high-fat diet plus fructose in rats. Free Radic Biol Med 47: 1067-1074.

ARULSELVAN P AND SUBRAMANIAN SP. 2007. Beneficial effects of Murraya koenigii leaves on antioxidant defense system and ultra structural changes of pancreatic betacells in experimental diabetes in rats. Chem Biol Interact 165: $155-164$. 
Axelsen LN, Lademann JB, Petersen JS, HolsteinRathlou Nh, Ploug T, Prats C, Pedersen HD and KJolbYe AL. 2010. Cardiac and metabolic changes in long-term high fructose-fat fed rats with severe obesity and extensive intramyocardial lipid accumulation. Am J Physiol Regul Integr Comp Physiol 298: R1560-R1570.

Bastard JP, MaAchi M, Lagathu C, Kim MJ, Caron M, VidAL H, CAPEAU J AND FEVE B. 2006. Recent advances in the relationship between obesity, inflammation, and insulin resistance. Eur Cytokine Netw 17: 4-12.

BLIGH EG AND DYER WJ. 1959. A rapid method of total lipid extraction and purification. Can J Biochem Physiol 37: 911-917.

BOYLE PJ. 2004. What are the effects of peroxisome proliferatoractivated receptor agonists on adiponectin, tumor necrosis factor-alpha, and other cytokines in insulin resistance? Clin Cardiol 27: IV11-IV16.

BREWER JR HB. 1999. Hypertriglyceridemia: changes in the plasma lipoproteins associated with an increased risk of cardiovascular disease. Am J Cardiol 83: 3F-12F.

Chang SL, LIN JG, ChI TC, LIU IM AND Cheng JT. 1999. An insulin-dependent hypoglycaemia induced by electroacupuncture at the Zhongwan (CV12) acupoint in diabetic rats. Diabetologia 42: 250-255.

Chao L, Marcus-Samuels B, Mason MM, Moitra J, Vinson C, Arioglu E, Gavrilova O and Reitman ML. 2000. Adipose tissue is required for the antidiabetic, but not for the hypolipidemic, effect of thiazolidinediones. J Clin Invest 106: 1221-1228.

DAlpe-Scott M, Heick HM And Begin-Heick N. 1982. An improved double antibody radioimmunoassay for the determination of insulin in serum, plasma, and tissue incubation media. Can J Biochem 60: 962-966.

Emilien G, Maloteaux JM AND Ponchon M. 1999. Pharmacological management of diabetes: recent progress and future perspective in daily drug treatment. Pharmacol Ther 81: 37-51.

FAUST IM, JOHnson PR, STERn JS AND HIRSCH J. 1978. Dietinduced adipocyte number increase in adult rats: a new model of obesity. Am J Physiol 235: E279-E286.

Festi D, Colecchia A, SAcco T, Bondi M, Roda E AND MARCHESINI G. 2004. Hepatic steatosis in obese patients: clinical aspects and prognostic significance. Obes Rev 5: 27-42.

FLEGAL KM, CARROLL MD, KUCZMARSKI RJ AND JOHNSON CL. 1998. Overweight and obesity in the United States: prevalence and trends, 1960-1994. Int J Obes Relat Metab Disord 22: 39-47.

Fossati P AND PRENCIPE L. 1982. Serum triglycerides determined colorimetrically with an enzyme that produces hydrogen peroxide. Clin Chem 28: 2077-2080.

FRIEDEWALD WT, LEVY RI AND FREDRICKSON DS. 1972. Estimation of the concentration of low-density lipoprotein cholesterol in plasma, without use of the preparative ultracentrifuge. Clin Chem 18: 499-502.

Giron MD, SeVillano N, Salto R, Haidour A, Manzano M, JiMENEZ ML, RUEDA R AND LOPEZ-PEDROSA JM. 2009. Salacia oblonga extract increases glucose transporter 4-mediated glucose uptake in L6 rat myotubes: role of mangiferin. Clin Nutr 28: 565-574.
GuHA S, GHOSAL S AND ChatTOPADHYAY U. 1996. Antitumor, immunomodulatory and anti-HIV effect of mangiferin, a naturally occurring glucosylxanthone. Chemotherapy 42 : 443-451.

Guo F, Huang C, Liao X, Wang Y, He Y, Feng R, Li Y AND SuN C. 2011. Beneficial effects of mangiferin on hyperlipidemia in high-fat-fed hamsters. Mol Nutr Food Res 55: 1809-1818.

HARRISON SA, KADAKIA S, LANG KA AND SCHENKER S. 2002. Nonalcoholic steatohepatitis: what we know in the new millennium. Am J Gastroenterol 97: 2714-2724.

HoA NK, Phan DV, ThuAN ND AND OsTenson CG. 2004. Insulin secretion is stimulated by ethanol extract of Anemarrhena asphodeloides in isolated islet of healthy Wistar and diabetic Goto-Kakizaki Rats. Exp Clin Endocrinol Diabetes 112: 520-525.

Holguin F, RoJAs M AND HART CM. 2007. The peroxisome proliferator activated receptor gamma (PPARgamma) ligand rosiglitazone modulates bronchoalveolar lavage levels of leptin, adiponectin, and inflammatory cytokines in lean and obese mice. Lung 185: 367-372.

Hotamisligil GS, Shargill NS AND Spiegelman BM. 1993. Adipose expression of tumor necrosis factoralpha: direct role in obesity-linked insulin resistance. Science 259: 87-91.

Hotta K ET AL. 2000. Plasma concentrations of a novel, adipose-specific protein, adiponectin, in type 2 diabetic patients. Arterioscler Thromb Vasc Biol 20: 1595-1599.

HotTA K, FunAHASHI T, BodKIN NL, ORTMEYER HK, ARITA Y, Hansen BC and Matsuzawa Y. 2001. Circulating concentrations of the adipocyte protein adiponectin are decreased in parallel with reduced insulin sensitivity during the progression to type 2 diabetes in rhesus monkeys. Diabetes 50: 1126-1133.

Hung HY, QIAN K, MorRis-NATSCHKe SL, Hsu CS AND LEE KH. 2012. Recent discovery of plant-derived anti-diabetic natural products. Nat Prod Rep 29: 580-606.

IWAKI M, MATSUdA M, MAEDA N, FUNAHASHI T, MATSUZAWA Y, MAKISHIMA M AND SHIMOMURA I. 2003. Induction of adiponectin, a fat-derived antidiabetic and antiatherogenic factor, by nuclear receptors. Diabetes 52: 1655-1663.

JoUAD H, EDDOUKS M, LACAILLE-DUBOIS MA AND LyOUSSI B. 2000. Hypoglycaemic effect of spergularia purpurea in normal and streptozotocin-induced diabetic rats. J Ethnopharmacol 71: 169-177.

KeRn PA, RANGanathan S, Li C, WoOD L AND RANGANATHAN G. 2001. Adipose tissue tumor necrosis factor and interleukin-6 expression in human obesity and insulin resistance. Am J Physiol Endocrinol Metab 280: E745-E751.

KERSTEN S, DESVERGNE B AND WAHLI W. 2000. Roles of PPARs in health and disease. Nature 405: 421-424.

LeIro J, ARranz JA, YANEZ M, Ubeira FM, SANMARtin ML AND ORALlO F. 2004. Expression profiles of genes involved in the mouse nuclear factor-kappa B signal transduction pathway are modulated by mangiferin. Int Immunopharmacol 4: 763-778. 
LIM S, SON KR, SONG IC, PARK HS, JIN CJ, JANG HC, PARK KS, KIM YB AND LEE HK. 2009. Fat in liver/muscle correlates more strongly with insulin sensitivity in rats than abdominal fat. Obesity (Silver Spring) 17: 188-195.

LIU S, Wu HJ, ZHANG ZQ, CHEN Q, LIU B, Wu JP AND ZHU L. 2011. The ameliorating effect of rosiglitazone on experimental nonalcoholic steatohepatitis is associated with regulating adiponectin receptor expression in rats. Eur J Pharmacol 650: 384-389.

LONARDO A, LOMBARDINI S, RICCHI M, SCAGLIONI F AND LORIA P. 2005. Review article: hepatic steatosis and insulin resistance. Aliment Pharmacol Ther 22 (Suppl 2): 64-70.

LOPES-VIRELLA MF, STONE PG AND COLWELL JA. 1977. Serum high density lipoprotein in diabetic patients. Diabetologia 13: 285-291.

MARKHAM R, YOUNG L AND FRASER IS. 1995. An amplified ELISA for human tumour necrosis factor alpha. Eur Cytokine Netw 6: 49-54.

MATKOWSKI A, KUS P, GORALSKA E AND WOZNIAK D. 2013. Mangiferin - a bioactive xanthonoid, not only from mango and not just antioxidant. Mini Rev Med Chem 13: 439-455.

MatThews DR, Hosker JP, RUdenski AS, NAYLOR BA, TREACHER DF AND TURNER RC. 1985. Homeostasis model assessment: insulin resistance and beta-cell function from fasting plasma glucose and insulin concentrations in man. Diabetologia 28: 412-419.

MiURA T ET AL. 2001a. Antidiabetic activity of a xanthone compound, mangiferin. Phytomedicine 8: 85-87.

MiURA T, IWAMOTO N, Kato M, ICHIKI H, KUBO M, KOMATSU Y, ISHIDA T, OKADA M AND TANIGAWA K. 2001b. The suppressive effect of mangiferin with exercise on blood lipids in type 2 diabetes. Biol Pharm Bull 24: 1091-1092.

MOLLER DE AND FLIER JS. 1991. Insulin resistance--mechanisms, syndromes, and implications. N Engl J Med 325: 938-948.

MuRAT JC AND SERFATY A. 1974. Simple enzymatic determination of polysaccharide (glycogen) content of animal tissues. Clin Chem 20: 1576-1577.

Muruganandan S, SRINIVASAN K, GUPTA S, GUPTA PK AND LAL J. 2005. Effect of mangiferin on hyperglycemia and atherogenicity in streptozotocin diabetic rats. J Ethnopharmacol 97: 497-501.

PSCHERER S, HEEMANN U AND FRANK H. 2010. Effect of ReninAngiotensin system blockade on insulin resistance and inflammatory parameters in patients with impaired glucose tolerance. Diabetes Care 33: 914-919.

PURI P ET AL. 2009. The plasma lipidomic signature of nonalcoholic steatohepatitis. Hepatology 50: 1827-1838.

RAGOlia L AND Begum N. 1998. Protein phosphatase-1 and insulin action. Mol Cell Biochem 182: 49-58.

Randle PJ, Garland PB, Hales CN AND Newsholme EA. 1963. The glucose fatty-acid cycle. Its role in insulin sensitivity and the metabolic disturbances of diabetes mellitus. Lancet 1: 785-789.

RATZIU V ET AL. 2008. Rosiglitazone for nonalcoholic steatohepatitis: one-year results of the randomized placebocontrolled Fatty Liver Improvement with Rosiglitazone Therapy (FLIRT) Trial. Gastroenterology 135: 100-110.
REAVEN GM AND Ho H. 1991. Low-dose streptozotocin-induced diabetes in the spontaneously hypertensive rat. Metabolism 40: 335-337.

Reed MJ, Meszaros K, Entes LJ, Claypool mD, Pinkett JG, GADBOIS TM AND REAVEN GM. 2000. A new rat model of type 2 diabetes: the fat-fed, streptozotocin-treated rat. Metabolism 49: 1390-1394.

RISCH L ET AL. 2006. Evaluation of two fully automated novel enzyme-linked immunosorbent assays for the determination of human adiponectin in serum. Clin Chim Acta 373: 121-126.

Ruan H, Pownall HJ AND LODISH HF. 2003. Troglitazone antagonizes tumor necrosis factor-alpha-induced reprogramming of adipocyte gene expression by inhibiting the transcriptional regulatory functions of NF-kappaB. J Biol Chem 278: 28181-28192.

SAgud M, MiHAlJEVIC-PEles A, PivaC N, JAKOVLJEVIC M AND MUCK-SELER D. 2009. Lipid levels in female patients with affective disorders. Psychiatry Res 168: 218-221.

SANCHEZ GM, RE L, GIULIANI A, NUNEZ-SELlES AJ, DAVISON GP AND LEON-FERNANDEZ OS. 2000. Protective effects of Mangifera indica L. extract, mangiferin and selected antioxidants against TPA-induced biomolecules oxidation and peritoneal macrophage activation in mice. Pharmacol Res 42: 565-573.

SAXENA A AND VIKRAM NK. 2004. Role of selected Indian plants in management of type 2 diabetes: a review. J Altern Complement Med 10: 369-378.

SCHAALAN M, EL-ABHAR HS, BARAKAT M AND EL-DENSHARY ES. 2009. Westernized-like-diet-fed rats: effect on glucose homeostasis, lipid profile, and adipocyte hormones and their modulation by rosiglitazone and glimepiride. J Diabetes Complications 23: 199-208.

Seda O, Kazdova L, Krenova D and Kren V. 2002. Rosiglitazone improves insulin resistance, lipid profile and promotes adiposity in a genetic model of metabolic syndrome X. Folia Biol (Praha) 48: 237-241.

SEllamuthu PS, ARUlSElvan P, FAKURAZI S AND KANDASAMY M. 2014. Beneficial effects of mangiferin isolated from Salacia chinensis on biochemical and hematological parameters in rats with streptozotocininduced diabetes. Pak J Pharm Sci 27: 161-167.

Sellamuthu PS, ARUlselvan P, Kamalraj S, FaKURAZI S AND KANDASAMY M. 2013a. Protective nature of mangiferin on oxidative stress and antioxidant status in tissues of streptozotocin-induced diabetic rats. ISRN Pharmacol 2013: 750109.

SEllamuthu PS, ARULSELVAN P, MuniapPan BP, FAKURAZI S AND KANDASAMY M. 2013b. Mangiferin from Salacia chinensis prevents oxidative stress and protects pancreatic beta-cells in streptozotocin-induced diabetic rats. J Med Food 16: 719-727.

SKurk T, ALberTi-Huber C, Herder C AND HAunER H. 2007. Relationship between adipocyte size and adipokine expression and secretion. J Clin Endocrinol Metab 92: 1023-1033.

SORG DA AND BuCKNER B. 1964. A Simple Method of Obtaining Venous Blood from Small Laboratory Animals. Proc Soc Exp Biol Med 115: 1131-1132. 
SRINIVASAN K, VisWANAD B, ASRat L, KaUl CL AND RAMARAO P. 2005. Combination of high-fat diet-fed and low-dose streptozotocin-treated rat: a model for type 2 diabetes and pharmacological screening. Pharmacol Res 52: 313-320.

TRINDER P. 1969. Determination of blood glucose using an oxidase-peroxidase system with a non-carcinogenic chromogen. J Clin Pathol 22: 158-161.

YAMAUCHI T ET AL. 2003. Cloning of adiponectin receptors that mediate antidiabetic metabolic effects. Nature 423: 762-769.

Yoon MJ, LeE GY, CHUNG JJ, AHN YH, Hong SH AND KIM JB. 2006. Adiponectin increases fatty acid oxidation in skeletal muscle cells by sequential activation of AMP-activated protein kinase, p38 mitogen-activated protein kinase, and peroxisome proliferator-activated receptor alpha. Diabetes 55: 2562-2570.

YOOSOOK C, BUNYAPRAPHATSARA N, BOONYAKIAT Y AND KANTASUK C. 2000. Anti-herpes simplex virus activities of crude water extracts of Thai medicinal plants. Phytomedicine 6: 411-419.

YOSHIKAWAM, NISHIDAN, SHIMODAH, TAKADAM, KAWAHARA Y AND MATSUdA H. 2001. Polyphenol constituents from Salacia species: quantitative analysis of mangiferin with alpha-glucosidase and aldose reductase inhibitory activities. Yakugaku Zasshi 121: 371-378.

Zhou M, Xu A, LAM KS, TAM PK, ChE CM, Chan L, LEE IK, WU D AND WANG Y.2010. Rosiglitazone promotes fatty acyl CoA accumulation and excessive glycogen storage in livers of mice without adiponectin. J Hepatol 53: 1108-1116.

\section{SUPPLEMENTARY MATERIAL}

Figure S1 - Effect of HFD-Fr for 4 weeks (HFD-4w) and HFDFr for 7 weeks accompanied by a daily dose of insulin (0.5 IU/ $\mathrm{kg}$ ) during the $7^{\text {th }}$ week (Obese resistant rats) on: a) body weight, b) serum glucose level $(\mathrm{mg} / \mathrm{dl})$, c) serum insulin level $(\mu \mathrm{IU} / \mathrm{ml})$, d) HOMA-IR and e) $\beta$-cell function. Data are presented as mean \pm S.E.M ( $\mathrm{n}=8-10)$ * Significantly different from control group, \# Significantly different from diabetic resistant group at $\mathrm{P}<$ 0.05 using one-way ANOVA followed by Tukey's post Hoc test.

Figure S2 - Effect of HFD-Fr for 7 weeks accompanied by a daily dose of insulin $(0.5 \mathrm{IU} / \mathrm{kg})$ during the $7^{\text {th }}$ week (Obese resistant rats) on: a) serum TG level (mg/dl), b) serum TC level (mg/dl), c) serum LDL-C level (mg/dl) d) serum HDL-C level $(\mathrm{mg} / \mathrm{dl})$ and e) atherogenic index. Data are presented as mean \pm S.E.M ( $\mathrm{n}=8-10)$ * Significantly different from control group, \# Significantly different from diabetic resistant group at $\mathrm{P}<0.05$ using one-way ANOVA followed by Tukey's post Hoc test.

Figure S3 - Effect of HFD-Fr for 7 weeks accompanied by a daily dose of insulin $(0.5 \mathrm{IU} / \mathrm{kg})$ during the $7^{\text {th }}$ week (Obese resistant rats) on: a) serum TNF- $\alpha$ level (pg/ml) and b) serum adiponectin level ( $\mathrm{ng} / \mathrm{ml})$. Data are presented as mean \pm S.E.M $(\mathrm{n}=8-10)$. * Significantly different from control group, \# Significantly different from diabetic resistant group at $\mathrm{P}<0.05$ using one-way ANOVA followed by Tukey's post Hoc test. 
